\title{
PENGARUH PERTUMBUHAN PENDAPATAN, CURRENT RATIO DAN DEBT TO EQUITY TERHADAP RETURN ON EQUITY PADA PERUSAHAAN PERKEBUNAN DI BURSA EFEK INDONESIA 2010-2017
}

\begin{tabular}{|c|c|}
\hline \multicolumn{2}{|c|}{ Ifa Nurmasari ${ }^{1}$} \\
\hline $\begin{array}{l}\text { ARTICLES } \\
\text { INFORMATION }\end{array}$ & ABSTRACT \\
\hline
\end{tabular}

\section{JURNAL SEKURITAS}

(Saham, Ekonomi, Keuangan dan Investasi )

Vol.2, No.3, Mei 2019

Halaman : $34-44$

C LPPM \& Prodi Manajemen

UNVERSITAS PAMULANG

ISSN (online) : 2581-2777

ISSN (print) : :2581-2696

Keyword:

CR, ROE, DER, Pertumbuhan

Pendapatan.

JEL. classification :

C33, G20, G23, N65

\section{Contact Author :}

PRODI MANAJEMEN UNPAM

JL.Surya Kencana No.1 Pamulang

Tangerang Selatan - Banten

Telp. (021) 7412566, Fax (021) 7412491

Email :

jurnalfinance.unpam@gmail.com
Penelitian ini mempunyai tujuan untuk mengetahui apakah terdapat pengaruh signifikan pertumbuhan pendapatan, Current Ratio dan Debt to Equity Ratio terhadap Return on Equity baik secara partial maupun simultan, pada perusahaan perkebunan di Bursa Efek Indonesia. Teknik yang digunakan dalam penelitian ini adalah purposing sampling, yaitu data diambil dari perusahaan perkebunan yang sudah terdaftar di Bursa Efek Indonesia minimal sejak 1 Januari 2010 dan perusahaan tersebut mempunyai data yang lengkap. Pengolahan data pada penelitian ini menggunakan eviews versi 10. Data yang digunakan adalah data panel, yang terdiri dari 5 perusahaan (data cross section) dan 8 tahun (data time series). Untuk menentukan model yang paling sesuai dengan penelitian ini dilakukan berbagai macam uji, yaitu : uji common effect, uji fixed effect, uji random, uji chow, uji housman dan uji lagrange multiplier. Setelah mendapatakan model yang sesuai dilanjutkan dengan uji asumsi klasik dan uji hipotesis. Hasil dari penelitian ini menunjukan bahwa pertumbuhan pendapatan dan Debt to Equity Ratio secara partial berpengaruh signifikan terhadap Return on Equity. Sedangkan Current Ratio secara partial tidak berpengaruh signifikan terhadap Return on Equity. Sedangkan secara simultan, pertumbuhan pendapatan, Current Ratio dan Debt to Equity Ratio berpengaruh signifikan sebesar $45,18 \%$.

This study aims to determine whether there is a significant effect of revenue growth, Current Ratio and Debt to Equity Ratio on Return on Equity both partially and simultaneously, in plantation companies in the Indonesia Stock Exchange. The technique used in this study is purposing sampling, ie data taken from plantation companies that have been listed on the Indonesia Stock Exchange at least January 1, 2010 and the company has complete data. Data processing in this study uses eviews version 10. The data used is panel data, which consists of 5 companies (cross section data) and 8 years (time series data). To determine the model that best fits this research, various types of tests are carried out, namely: common effect test, fixed effect test, random test, chow test, housman test and lagrange multiplier test. After obtaining the appropriate model, it is continued with the classic assumption test and hypothesis test. The results of this study show that revenue growth and Debt to Equity Ratio partially have a significant effect on Return on Equity. While the Current Ratio partially does not have a significant effect on Return on Equity. Simultaneously, revenue growth, Current Ratio and Debt to Equity Ratio have a significant effect of $45.18 \%$. 


\section{A. Pendahuluan}

Kinerja keuangan perusahaan merupakan salah satu hal yang menjadi perhatian baik oleh perusahaan itu sendiri maupun oleh investor. Kinerja keuangan menggambarkan bagaimana keputusan manajemen perusahaan dalam mendapatkan dan mengelola modal, sampai dengan menghasilkan keuntungan.

Kinerja keuangan menjadi hal yang diperhatikan investor pada saat investor akan menanamkan modalnya di suatu perusahaan. Kinerja keuangan yang bagus tentu saja akan menarik banyak investor untuk berinvestasi pada perusahaan tersebut. Kinerja keuangan dapat dilihat dari keuntungan yang dihasilkan oleh perusahaan. Rasio keuangan yang menunjukkan bagaimana kemampuan perusahaan dalam menghasilkan laba, salah satunya adalah Return on Equity (ROE). Menurut Sutrisno (2013:229), "Return on Equity ini sering disebut dengan rate of return on Net Worth yaitu kemampuan perusahaan dalam menghasilkan keuntungan dengan modal sendiri yang dimiliki”.

Tingkat pertumbuhan pendapatan suatu perusahaan sangat mempengaruhi laba bersih yang akan diperoleh. Ketika perusahaan mengalami pertumbuhan pendapatan, dan beban yang dikeluarka tetap dibandingkan dengan tahun sebelumnya, maka laba bersih yang diperoleh perusahaan tersebut akan meningkat.

Tingkat keuntungan yang diperoleh suatu perusahaan dipengaruhi oleh banyak hal, salah satunya adalah hutang. Hutang merupakan salah satu bentuk modal, selain surat berharga dan laba ditahan. Jika perusahaan mempunyai banyak hutang, maka beban yang harus dikeluarkan perusahaan untuk membayar bunga semakin tinggi. Sehingga keuntungan yang didapat perusahaan akan berkurang. Salah satu bentuk rasio yang menggambarkan hutang yang dimiliki perusahaan adalah Debt to Equity Ratio (DER). Debt to Equity Ratio (DER) adalah perbandingan antara hutang yang dimiliki perusahaan dengan modal sendiri.

Kemampuan perusahaan dalam membayar hutang, khususnya hutang jangka pendek memperlihatkan kinerja keuangan perusahaan. Perusahaan akan mengambil keputusan, berapa jumlah aktiva lancar yang harus tersedia agar dapat mambayar hutang lancarnya. Jika aktiva lancar perusahaan terlalu besar, para investor akan berfikir bahwa perusahaan tidak memanfaatkan uang yang ada untuk investasi pengembangan usaha. Namun jika jumlahnya terlalu sedikit, akan mempengaruhi kelancaran dalam melunasi hutang jangka pendek. Rasio keuangan yang menunjukkan kemampuan perusahaan dalam membayar hutang jangka pendek adalah Current Ratio (CR). Current Ratio (CR) merupakan rasio yang membandingkan antara aktiva lancar dengan hutang jangka pendek yang dimiliki perusahaan.

Tabel 1

Return on Equity

\begin{tabular}{|c|c|c|c|c|c|}
\hline \multirow{2}{*}{ Tahun } & \multicolumn{5}{|c|}{ Perusahaan } \\
\cline { 2 - 6 } & $\begin{array}{c}\text { AALI } \\
(\%)\end{array}$ & $\begin{array}{c}\text { BWPT } \\
(\%)\end{array}$ & $\begin{array}{c}\text { LSIP } \\
(\%)\end{array}$ & $\begin{array}{c}\text { SMAR } \\
(\%)\end{array}$ & $\begin{array}{c}\text { TBLA } \\
(\%)\end{array}$ \\
\hline $\mathbf{2 0 1 0}$ & 28 & 22 & 23 & 22 & 20 \\
\hline $\mathbf{2 0 1 1}$ & 30 & 22 & 29 & 24 & 26 \\
\hline $\mathbf{2 0 1 2}$ & 27 & 16 & 18 & 24 & 14 \\
\hline $\mathbf{2 0 1 3}$ & 19 & 8 & 12 & 14 & 5 \\
\hline $\mathbf{2 0 1 4}$ & 22 & 3 & 13 & 19 & 18 \\
\hline $\mathbf{2 0 1 5}$ & 6 & -3 & 8 & -5 & 7 \\
\hline $\mathbf{2 0 1 6}$ & 12 & 6 & 8 & 25 & 18 \\
\hline $\mathbf{2 0 1 7}$ & 11 & -3 & 10 & 10 & 24 \\
\hline
\end{tabular}

Sumber : Laporan keuangan perusahaan 
Indonesia merupakan salah satu Negara terbesar pengekspor hasil perkebunan khususnya kelapa sawit. Kinerja keuangan perusahaan perkebunan sering menjadi perhatian investor. Tujuan investor dalam menginvestasikan uangnya adalah untuk mendapatkan keuntungan. Oleh karena itu investor akan memilih untuk berinvestasi pada perusahaan yang menghasilkan keuntungan yang besar. Tabel 1 memperlihatkan laba perusahaan perkebunan yang dalam hal ini ditunjukkan oleh Return on Equity. Return on Equity (ROE) pada perusahaan perkebunan nilainya masih berfluktuasi dari tahun 2010 sampai 2017.

Laba perusahaan perkebunan menjadi hal yang diperhatikan oleh investor. Laba yang dihasilkan perusahaan ini dipengaruhi oleh banyak hal, diantaranya adalah pertumbuhan pendapatan, Current Ratio dan Debt to Equity Ratio. Oleh karena itu, akan dilakukan penelitian dengan judul "Pengaruh Pertumbuhan Pendapatan, Current Ratio dan Debt to Equity Ratio Terhadap Return on Equity pada Perusahaan Perkebunan di BEI tahun 2010-2017."

\section{B. Perumusan Masalah}

Pada penelitian ini, rumusan masalah dapat diuraikan sebagai berikut :

1. Apakah terdapat pengaruh signifikan pertumbuhan pendapatan terhadap Return on Equity?

2. Apakah terdapat pengaruh signifikan Current Ratio terhadap Return on Equity?

3. Apakah terdapat pengaruh signifikan Debt to Equty Ratio terhadap Return on Equity?

4. Apakah terdapat pengaruh signifikan pertumbuhan pendapatan, Current Ratio dan Debt to Equity Ratio secara simultan terhadap Return on Equity?

\section{Kerangka Berpikir}

Kerangka berfikir dari penelitian ini dapat digambarkan sebagai berikut:

\section{PENGARUH PERTUMBUHAN PENDAPATAN, CR, DAN DER TERHADAP ROE PADA PERUSAHAAN PERKEBUNAN DI BEI 2010-2017}

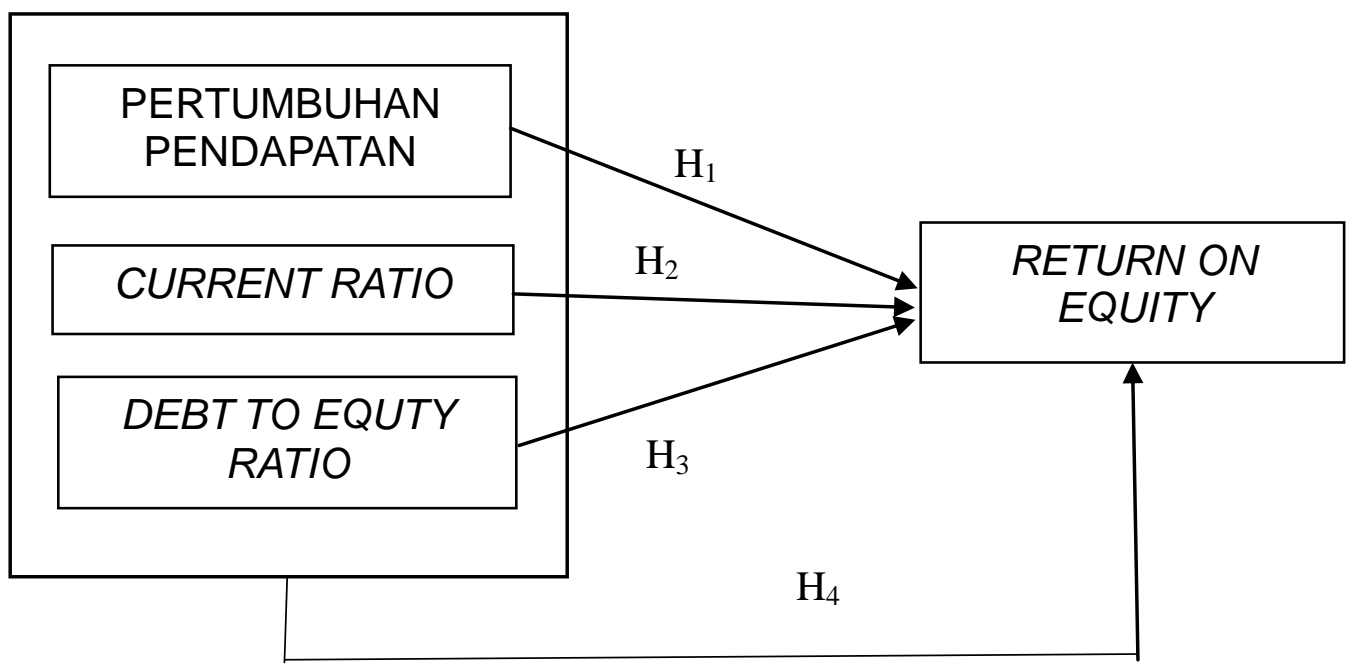

Gambar 1

Kerangka Berpikir 


\section{Landasan Teori}

\section{Return on Equity}

Return on Equity merupakan salah satu jenis rasio profitabilitas, Rasio profitabilitas menunjukkan efisiensi manajemen perusahaan dalam menghasilkan laba. Menurut Kasmir (2015:204), "hasil pengembalian ekuitas atau return on equity atau rentabilitas modal sendiri merupakan rasio untuk mengukur laba bersih sesudah pajak dengan modal sendiri". Nilai return on equity ini menunjukkan bagaimana kemampuan perusahaan dalam mengelola modal sendiri. Apabila nilai return on equity ini tinggi, maka menunjukkan keadaan perusahaan yang semakin baik, demikian juga sebaliknya. Nilai return on equity bisa dicari dengan menggunakan rumus sebagai berikut:

$$
\text { Return on Equity }=\frac{\text { Earning After Interest and Tax }}{\text { Equity }}
$$

\section{Pertumbuhan Pendapatan}

Pertumbuhan pendapatan menunjukkan persentase dari selisih pendapatan perusahaan dibandingkan dengan tahun sebelumnya. Pertumbuhan pendapatan bernilai positif berarti menunjukkan adanya kenaikan pendapatan yang diperoleh perusahaan dibandingkan dengan tahun sebelumnya. Sedangkan pertumbuhan pendapatan bernilai negatif menunjukkan adanya penurunan pendapatan dibandingkan tahun bsebelumnya. Nilai pertumbuhan pendapatan ini dapat diperoleh dari rumus berikut :

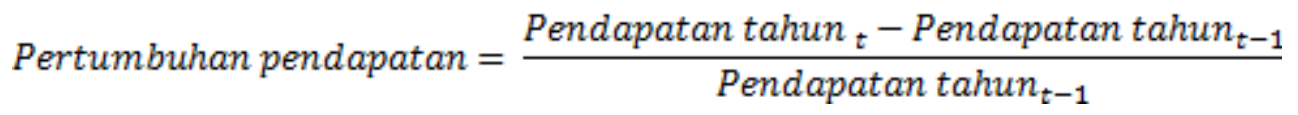

\section{Current Ratio}

Current Ratio merupakan bagian dari rasio likuiditas. Rasio likuiditas menggambarkan apakah perusahaan mampu atau tidak dalam membayar utang jangka pendeknya. Menurut Kasmir (2015:134), "rasio lancar atau current ratio merupakan rasio untuk mengukur kemampuan perusahaan dalam membayar kewajiban jangka pendek atau utang yang segera jatuh tempo pada saat ditagih secara keseluruhan". Apabila nilai current ratio rendah, hal ini dapat menunjukkan bahwa perusahaan sedang kekurangan modal untuk membayar utang jangka pendeknya. Namun apabila nilainya tinggi, juga tidak sedang menunjukkan kondisi perusahaan yang baik, karena bisa jadi perusahaan tidak mampu dalam mengelola kasnya. Nilai current ratio ini dapat dicari dengan menggunakan rumus berikut :

$$
\text { Current ratio }=\frac{\text { Aktiva Lancar }}{\text { Hutang Lancar }}
$$

\section{Debt to Equity Ratio}

Debt to Equity Ratio merupakan bagian dari rasio solvabilitas atau leverage. Menurut Kasmir (2015:151), "Rasio solvabilitas atau leverage ratio merupakan rasio yang digunakan untuk mengukur sejauh mana aktiva peusahaan dibiayai dengan utang". Rasio solvabilitas atau leverage ini digunakan untuk mengukur bagaimana kemampuan perusahaan dalam membayar hutangnya, baik yang jangka panjang maupun yang jangka pendek. "Debt to equity ratio merupakan rasio yang digunakan untuk menilai utang dengan equitas" (Kasmir, 2015:157). Bagi kreditor, apabila nilai Debt to Equity Ratio semakin tinggi akan semakin berisiko, karena dikhawatirkan perusahaan tidak mampu membayar utang. Sedangkan bagi perusahaan, nilai Debt to Equity Ratio yang rendah, menyebabkan perusahaan harus menyediakan dana sendiri dalam jumlah yang lebih banyak. Hal ini menyebabkan resiko yang lebih tinggi bagi pemiliknya. Nilai Debt to Equity Ratio ini dapat dicari dengan menggunakan rumus sebagai berikut. 


$$
\text { Debt to Equity Ratio }=\frac{\text { Total Utang }}{\text { Ekuitas }}
$$

\section{E. Metodologi Penelitian}

Data pada penelitian ini berjenis kuantitatif, yang akan diambil dari perusahaan perkebunan yang terdapat di Bursa Efek Indonesia pada tahun 2010-2017. Data yang didapatkan, akan diolah dengan menggunakan eviews versi 10. Penelitian ini dilakukan untuk mengetahui bagaimana pengaruh dari pertumbuhan pendapatan, Current Ratio dan Debt to Equity Ratio baik secara parsial maupun secara simultan terhadap Return on Equity pada perusahaan perkebunan yang ada di Indonesia.

\section{Populasi Dan Sampel}

1. Populasi

Pada penelitian ini, populasi yang digunakan adalah semua perusahaan sub sektor perkebunan di Indonesia yang telah terdaftar di Bursa Efek Indonesia. Jumlah perusahaan perkebunan di Indonesia yang telah terdaftar di Bursa Efek Indonesia ini ada 16 perusahaan.

2. Sampel

Sampel dalam penelitian ini diambil dengan menggunakan kriteria tertentu atau purposing sampling. Kriteria tersebut yaitu :

a. Perusahaan perkebunan harus sudah go publish minimal sejak 1 januari 2010 sampai 31 Desember 2017.

b. Data perusahaan harus lengkap.

Perusahaan perkebunan yang sudah go publish ada 16 perusahaan. Dari 16 perusahaan tersebut, hanya 7 perusahaan yang memenuhi kriteria purposing sampling. Dari 7 perusahaan tersebut, ada 2 perusahaan yang mempunyai data pencilan, sehingga tidak diikutkan pada penelitian ini. Data yang digunakan pada penelitian ini adalah data panel, terdiri dari data time series (yaitu dari tahun 2010 sampai 2017) dan data cross section (ada 5 perusahaan).

\section{Analisis Data}

Data yang sudah diperoleh, diolah dengan berbagai macam uji, yaitu uji estimasi model regresi linier, uji asumsi klasik dan uji hipotesis.

\section{Estimasi Model Regresi Linier}

Data panel yang diperoleh akan diolah dengan menggunakan software Eviews (Econometric Views) versi 10. Pada eviews ini terdapat tiga model regresi linier, yaitu model common effect, model fixed effect dan model random effect. Untuk memilih model mana yang paling sesuai, maka dilakukan uji chow, uji housman dan uji lagrange multiplier. Estimasi model yang digunakan dalam penelitian ini adalah sebagai berikut :

$$
Y_{\text {it }}=\beta_{0}+\beta_{1} X_{1, \text { it }}+\beta_{2} X_{2, i t}+\beta_{3} X_{3, i t}+\beta_{4} X_{4, i t}+\varepsilon_{i}
$$

\section{a. Uji Chow}

Uji Chow dilakukan untuk memilih antara model common effect dan model fixed effect, mana yang paling sesuai dengan data penelitian. Pada penelitian ini model fixed effect ternyata lebih baik dibandingkan dengan dengan model common effect.

\section{b. Uji Housman}

Uji Housman dilakukan untuk memilih antara model fixed effect dan model random effect, mana yang paling sesuai dengan data penelitian. Pada penelitian ini model fixed effect ternyata lebih baik dibandingkan dengan model random effect.

c. Uji Lagrange Multiplier 
Uji Lagrange Multiplier dilakukan untuk memilih antara model common effect dan model random effect, mana yang sesuai dengan data penelitian. Dari uji chow dan uji housman, model yang terpilih adalah model fixed effect. Maka tidak perlu dilakukan uji lagrange multiplier.

\section{Uji Asumsi Klasik}

Tujuan dilakukannya uji asumsi klasik adalah supaya hasil dari regresi linier memenuhi kriteria BLUE yaitu Best, Linear, Unbiased dan Estimator. Uji asumsi klasik yang dilakukan antara lain uji normalitas, uji multikolinearitas, uji autokorelasi dan uji heterokedastisitas.

\section{a. Uji Normalitas}

Hasil dari uji normalitas dengan menggunakan eviews versi 10 dapat dilihat pada gambar 2. Dari hasil uji normalitas, didapatkan nilai Jarque-Bera 1,877191<2 dan nilai probalilitas $0,391177>0,05$. Nilai ini menunjukkan bahwa data terdistribusi normal.

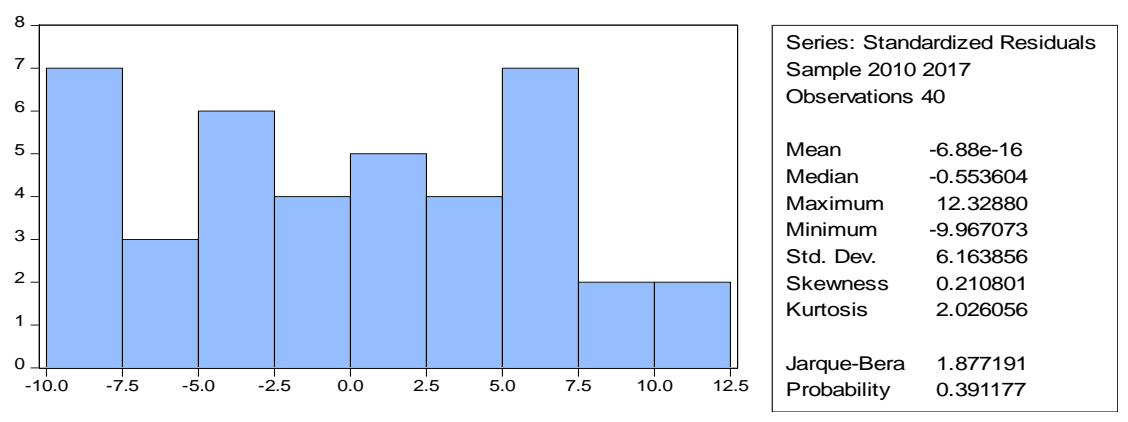

Gambar 2

Uji Normalitas

\section{b. Uji Multikolinearitas}

Uji Multikolinearitas dilakukan untuk mengetahui apakah antar variabel bebas terdapat hubungan linear. Hasil uji multikolinearitas dengan menggunakan eviews versi 10, dapat dilihat pada tabel 2. Dari tabel 2 tersebut, bisa kita lihat bahwa nilai antar variabel bebas tidak ada yang lebih dari 0,8. Hal ini berarti antar variabel bebas tidak terdapat multikolinearitas.

Tabel 2

Uji Multikolinearitas

\begin{tabular}{|c|c|c|c|}
\hline & PP & CR & DER \\
\hline PP & 1.000000 & -0.118316 & 0.198527 \\
\hline CR & -0.118316 & 1.000000 & -0.464703 \\
\hline DER & 0.198527 & -0.464703 & 1.000000 \\
\hline
\end{tabular}

Sumber: data penelitian diolah (2018)

\section{c. Uji Autokorelasi}

Menurut Wing Wahyu Winarno (2015:5.29), "Otokorelasi (autocorrelation) adalah hubungan antara residual satu observasi dengan residual observasi lainnya". Autokorelasi ini biasanya muncul pada data time series. Untuk melihat apakah terjadi autokorelasi atau tidak, dapat dilhat dari nilai Durbin-Watson. Menurut Jonathan Sarwono (2016:87)," Tidak terjadi autokorelasi jika nilainya : -2 $\leq \mathrm{DW} \leq 2$ ". Nilai Durbin Watson pada penelitian ini adalah 1.524990 (tabel 4), dengan demikian pada data ini tidak terjadi autokorelasi.

\section{d. Uji Heterokedastisitas}

Uji Heteroskedastisitas dilakukan untuk mengetahui apakah terjadi 
perbedaan variance residual dari satu pengamatan ke pengamatan lain pada model regresi. Untuk mengetahui apakah terjadi heterokedastisitas atau tidak, dapat dilakukan dengan uji gletser. Apabila nilai probabilitas pada semua variabel bebas nilainya lebih besar dari 0,05, maka tidak terdapat heterokedastisitas. Dari tabel 3, dapat dilihat bahwa nilai probabilitas pada variabel bebas nilainya lebih dari 0,05 . Dengan demikian model regresi pada penelitian ini tidak terdapat heterokedastisitas.

\section{Tabel 3}

Uji Gletser

\begin{tabular}{|c|c|c|c|c|}
\hline \multicolumn{5}{|c|}{$\begin{array}{l}\text { Dependent Variable: RESARB } \\
\text { Method: Panel Least Squares } \\
\text { Sample: } 20102017 \\
\text { Periods included: } 8 \\
\text { Cross-sections included: } 5 \\
\text { Total panel (balanced) observations: } 40\end{array}$} \\
\hline Variable & Coefficient & Std. Error & t-Statistic & Prob. \\
\hline$C$ & 5.374630 & 1.472211 & 3.650720 & 0.0008 \\
\hline $\mathrm{CR}$ & 0.004033 & 0.005400 & 0.746747 & 0.4601 \\
\hline DER & -0.005038 & 0.007781 & -0.647425 & 0.5215 \\
\hline PP & -0.004924 & 0.005097 & -0.966019 & 0.3405 \\
\hline
\end{tabular}

$\overline{\text { Sumber : Data penelitian diolah }} \overline{\overline{2018)}}$

\section{Uji Hipotesis}

Pada penelitian ini, model yang terpilih adalah model fixed effect, yang bisa dilihat pada tabel 4. Model ini sudah memenuhi uji asumsi klasik.

a. Uji t

Uji t dilakukan untuk mengetahui apakah terdapat pengaruh signifikan dari variabel bebas terhadap variabel terikat. Nilai t tabel pada penelitian ini adalah 2,028 .

\section{Pengaruh pertumbuhan pendapatan terhadap Return on Equity}

Nilai $t$ hitung dari pertumbuhan pendapatan yang didapatkan pada tabel 4 adalah 2,275. Pada pertumbuhan pendapatan diperoleh nilai $t$ hitung $>t$ tabel $(2,275>2,028)$ dengan nilai signifikansi $0,0297<0,05$. Hal ini menunjukkan bahwa $\mathrm{H}_{01}$ ditolak dan $\mathrm{H}_{\mathrm{a} 1}$ diterima artinya pertumbuhan pendapatan berpengaruh signifikan terhadap Return on Equity. Pertumbuhan pendapatan bertanda positif, hal ini menunjukkan bahwa pertumbuhan pendapatan dan Return on Equity mempunyai hubungan yang searah. Semakin besar nilai pertumbuhan pendapatan akan menyebabkan nilai Return on Equity menjadi besar.

\section{Pengaruh Current Ratio terhadap Return on Equity}

Nilai $t_{\text {hitung }}$ dari Current Ratio yang didapatkan pada tabel 4 adalah 0,0081. Pada Current Ratio diperoleh nilai $-\mathrm{t}_{\text {tabel }} \leq \mathrm{t}_{\text {hitung }} \leq+\mathrm{t}$ tabel $(-2,028 \leq 0,0081 \leq 2,028)$ dengan nilai signifikansi $0,9936>0,05$. Hal ini menunjukkan bahwa $\mathrm{H}_{02}$ diterima dan $\mathrm{H}_{\mathrm{a} 2}$ ditolak artinya Current Ratio tidak berpengaruh signifikan terhadap Return on Equity.

\section{Pengaruh Debt to Equity Ratio terhadap Return on Equity}

Nilai $t$ hitung dari Debt to Equity Ratio yang didapatkan pada tabel 4 adalah 4,930. Pada Debt to Equity Ratio diperoleh nilai $\mathrm{t}$ hitung $\leq-\mathrm{t}$ tabel $(-4,930 \leq-2,028)$ dengan nilai signifikansi $0,0000<0,05$. Hal ini menunjukkan bahwa $\mathrm{H}_{03}$ ditolak dan 
$\mathrm{H}_{\mathrm{a} 3}$ diterima artinya Debt to Equity Ratio berpengaruh signifikan terhadap Return on Equity. Debt to Equity Ratio bertanda negatif, hal ini menunjukkan bahwa Debt to Equity Ratio dan Return on Equity mempunyai hubungan yang berlawanan arah. Semakin besar nilai Debt to Equity Ratio akan menyebabkan nilai Return on Equity menjadi kecil dan juga sebaliknya.

Tabel 4

Regresi Linier Berganda (Fixed Effect)

Dependent Variable: ROE

Method: Panel Least Squares

Sample: 20102017

Periods included: 8

Cross-sections included: 5

Total panel (balanced) observations: 40

\begin{tabular}{|crlrr}
\hline \hline \multicolumn{1}{c}{ Variable } & Coefficient & Std. Error & t-Statistic & Prob. \\
\hline \hline C & 36.38612 & 5.478809 & 6.641246 & 0.0000 \\
PP & 0.027077 & 0.011901 & 2.275131 & 0.0297 \\
DER & 0.000121 & 0.014901 & 0.008121 & 0.9936 \\
& -0.198731 & 0.040307 & -4.930455 & 0.0000 \\
\hline \hline \multicolumn{5}{c}{ Effects Specification } \\
\hline \hline Cross-section fixed (dummy variables) & & \\
\hline \hline R-squared & 0.550227 & Mean dependent var & 15.30000 \\
Adjusted R-squared & 0.451839 & S.D. dependent var & 9.190854 \\
S.E. of regression & 6.804713 & Akaike info criterion & 6.849965 \\
Sum squared resid & 1481.732 & Schwarz criterion & 7.187740 \\
Log likelihood & -128.9993 & Hannan-Quinn criter. & 6.972094 \\
F-statistic & 5.592430 & Durbin-Watson stat & 1.524990 \\
Prob(F-statistic) & 0.000283 & & \\
\hline \hline
\end{tabular}

Sumber : Data penelitian diolah (2018)

b. Uji F

Uji F digunakan untuk mengetahui apakah terdapat pengaruh yang signifikan dari pertumbuhan pendapatan, Current Ratio dan Debt to Equity Ratio secara simultan terhadap Return on Equity. Nilai $\mathrm{F}$ tabel pada penelitian ini adalah 2,87, sehingga didapatkan nilai $F_{\text {hitung }}>F_{\text {tabel }}(5,592>2,87)$. Nilai probabilitas yang didapatkan adalah 0,0002 <0,05. Hal ini menunjukkan bahwa pertumbuhan pendapatan, Current Ratio dan Debt to Equity Ratio berpengaruh signifikan terhadap Return on Equity.

\section{c. Koefisien Determinasi}

Koefisien determinasi digunakan untuk mengetahui seberapa besar variabel bebas, yang dalam penelitian ini adalah pertumbuhan pendapatan, Current Ratio dan Debt to Equity ratio mempengaruhi variabel terikat yaitu Return on Equity. Nilai Adjusted $R$ squared adalah 0,4518. Ini artinya, secara simultan variabel bebas mempengaruhi $45,18 \%$ variabel terikatnya. 


\section{F. Pembahasan}

\section{Pengaruh Pertumbuhan Pendapatan Terhadap Return on Equity}

Hasil pengolahan data dengan menggunakan eviews 10 , memperlihatkan secara parsial pertumbuhan pendapatan berpengaruh positif signifikan terhadap Return on Equity. Hal ini ditunjukkan dengan nilai $t_{\text {hitung }}>\mathrm{t}_{\text {tabel }}$ yaitu 2,275>2,028. Selain dilihat dari nilai $t$ hitung dan $t$ tabel, pengaruh pertumbuhan pendapatan terhadap Return on Equity juga bisa dilihat dari nilai signifikansinya, yaitu sebesar 0,0297 . Nilai ini lebih kecil dari 0,05 . Hal ini menunjukkan bahwa $\mathrm{H}_{01}$ ditolak dan $\mathrm{H}_{\mathrm{a} 1}$ diterima, artinya pertumbuhan pendapatan berpengaruh signifikan terhadap Return on Equity.

Pendapatan perusahaan yang meningkat dibandingkan tahun sebelumnya, dapat menyebabkan laba perusahaan ikut meningkat. Laba perusahaan ini ikut meningkat apabila beban perusahaan tetap atau naik, namun dengan kenaikan yang tidak melebihi kenaikan pendapatan. Dari pengolahan data eviews, pertumbuhan pendapatan bertanda positif, hal ini menunjukkan bahwa pertumbuhan pendapatan dan Return on Equity mempunyai hubungan yang searah. Semakin besar nilai pertumbuhan pendapatan akan menyebabkan nilai Return on Equity menjadi besar.

\section{Pengaruh Current Ratio terhadap Return on Equity}

Hasil pengolahan data dengan menggunakan eviews 10, menunjukkan bahwa Current Ratio tidak berpengaruh signifikan terhadap Return on Equity. Hal ini ditunjukkan dengan nilai $t$ hitung Current Ratio sebesar 0,0081. Besarnya nilai $t$ hitung Current Ratio adalah $-\mathrm{t}$ tabel $\leq \mathrm{t}$ hitung $\leq+\mathrm{t}$ tabel atau sebesar $-2,028$ $\leq 0,0081 \leq 2,028$, dengan nilai signifikansi $0,9936>0,05$. Hal ini berarti $\mathrm{H}_{02}$ diterima dan $\mathrm{H}_{\mathrm{a} 2}$ ditolak artinya Current Ratio tidak berpengaruh signifikan terhadap.

Current Ratio menunjukkan kemampuan perusahaan dalam membayar hutang jangka pendek. Apabila nilai Current Ratio bertambah besar, hal ini menunjukkan semakin besar nilai aktiva lancar yang tersedia untuk membayar hutang jangka pendek. Namun apabila nilai Current Ratio ini terlalu besar maka investor akan menganggap perusahaan tidak bisa memanfaatkan nilai aktiva lancar yang besar ini untuk pengembangan usahanya.

\section{Pengaruh Debt to Equity Ratio terhadap Return on Equity}

Hasil pengolahan data dengan menggunakan eviews 10 , menunjukkan bahwa Debt to Equity Ratio berpengaruh negatif signifikan terhadap Return on Equity. Nilai $\mathrm{t}_{\text {hitung }}$ dari Debt to Equity Ratio adalah -4,930. Pada Debt to Equity Ratio diperoleh nilai $\mathrm{t}$ hitung $\leq-\mathrm{t}$ tabel $(-4,930 \leq-2,028)$ dengan nilai signifikansi $0,0000<0,05$. Hal ini menunjukkan bahwa $\mathrm{H}_{03}$ ditolak dan $\mathrm{H}_{\mathrm{a} 3}$ diterima, artinya Debt to Equity Ratio berpengaruh signifikan terhadap Return on Equity.

Semakin besar nilai Debt to Equity Ratio, menunjukkan semakin besar hutang perusahaan untuk membiayai perusahaan. Apabila hutang perusahaan semakin besar, maka beban perusahaan untuk membayar bunga dan pokok pinjaman semakin besar, dampaknya laba perusahaan semakin besar. Pada penelitian ini, Debt to Equity Ratio bertanda negative. hal ini menunjukkan bahwa Debt to Equity Ratio dan Return on Equity mempunyai hubungan yang berlawanan arah. Semakin besar nilai Debt to Equity Ratio akan menyebabkan nilai Return on Equity menjadi kecil dan juga sebaliknya.

4. Pengaruh Pertumbuhan Pendapatan, Current Ratio dan Debt to Equity Ratio terhadap Return Saham.

Hasil uji F, didapatkan hasil terdapat pengaruh yang signifikan dari pertumbuhan pendapatan, Current Ratio dan Debt to Equity Ratio secara simultan terhadap Return on Equity. Nilai $\mathrm{F}$ tabel pada penelitian ini adalah 2,87, sehingga didapatkan nilai $F_{\text {hitung }}>F_{\text {tabel }}(5,592>2,87)$. Nilai probabilitas yang didapatkan adalah 0,0002 <0,05. Nilai Adjusted R-squared sebesar 0,451839. Ini artinya 
variabel bebas yang terdiri dari pertumbuhan pendapatan, Current Ratio dan Debt to Equity Ratio memberikan pengaruh sebesar 45,18\% terhadap Return on Equity. Sedangkan sisanya sebesar $44,82 \%$ menunjukkan bahwa ada variabel lain yang tidak diteliti dalam penelitian ini yang mempengaruhi Return on Equity.

\section{G. Kesimpulan dan Saran}

1. Kesimpulan

a. Pertumbuhan pendapatan berpengaruh signifikan positif terhadap Return on Equity.

b. Current Ratio tidak berpengaruh signifikan terhadap Return on Equity.

c. Debt to Equity Ratio berpengaruh signifikan negatif terhadap Return on Equity.

d. Secara simultan, pertumbuhan pendapatan. Current Ratio dan Debt to Equity Ratio berpengaruh signifikan terhadap Return on Equity sebesar $45,18 \%$.

\section{Saran}

Saran yang ingin penulis sampaikan setelah melakukan penelitian ini adalah :

1. Hasil penelitian menunjukkan bahwa pertumbuhan pendapatan dan Debt to Equity Ratio berpengaruh signifikan terhadap Return on Equity. Oleh karena itu, untuk meningkatkan nilai Return on Equity, perusahaan sebaiknya meningkatkan nilai pertumbuhan pendapatan dan memperkecil nilai Debt to Equity Ratio.

2. Pertumbuhan Pendapatan, Current Ratio dan Debt to Equity Ratio secara simultan berpengaruh $45,18 \%$ terhadap Return on Equity. Ada variabel lain sebesar $54,82 \%$ yang mempengaruhi Return on Equity. Sebaiknya dilakukan penelitian dengan menggunakan variabel independen yang lain dan menggunakan data yang lebih banyak. 


\section{H. Daftar Pustaka}

Atmaja, L.S., 2008, "Teori dan Praktik Manajemen Keuangan”, Penerbit Andi, Yogyakarta.

Horne, V., James, C., John, M., dan Wachowicz, J.R., 2007, "Prinsip-prinsip Manajemen Keuangan", Penerbit Salemba Empat, Jakarta.

Husnan, S., dan Pudjiastuti, E., 2015, “Dasar-Dasar Manajemen Keuangan”, UPP STIM YKPN, Yogyakarta.

Kasmir, 2015, "Analisis Laporan Keuangan”, PT Raja Grafindo Persada, Jakarta.

Nachrowi, D., dan Usman, H., 2006, "Pendekatan Populer dan Praktis Ekonometrika Untuk Analisis Ekonomi dan Keuangan", Fakultas Ekonomi Universitas Indonesia, Jakarta.

Sunardi, N. (2017). Determinan Kebijakan Utang Serta Implikasinya terhadap Kinerja Perusahaan (Perusahaan yang tergabung dalam indeks LQ. 45 yang terdaftar di Bursa Efek Indonesia Tahun 2011-2015). Jurnal Sekuritas, 1(1).

Sunardi, N., Hamid, A. A., Lativa, A. K., \& Tulus, N. (2018). Determinant Of Cost Efficiency And It's Implications For Companies Performance Incorporated In The Lq. 45 Index Listing In Idx For The Period of 2011-2016. International Journal of Applied Business and Economic Research, 16(1).

Sunardi, N. (2019). Determinan Intelectual Capital dengan Pendekatan iB-VAIC TM Terhadap Efisiensi Biaya Implikasinya Pada Profitabilitas Perbankan Syariah di Indonesia. JIMF (Jurnal IImiah Manajemen Forkamma), 1(1).

Sunardi, N. (2018). Analisis Du Pont System Dengan Time Series Approach (Tsa) Dan Cross Sectional Approach (Csa) Dalam Penilaian Kinerja Keuangan Perusahaan (Studi Pada Industri Konstruksi (BUMN) di Indonesia Yang Listing di BEI Tahun 2013-2017). Jurnal SEKURITAS (Saham, Ekonomi, Keuangan dan Investasi), 1(4).

Sunardi, N., \& Sasmita, A. S. (2019). Pengaruh Likuiditas, Leverage Dan Growth Terhadap Kinerja Industri Makanan Dan Minuman Yang Tercatat Di Indonesia Stock Exchange Selama Periode Tahun 2011-2015. Jurnal SEKURITAS (Saham, Ekonomi, Keuangan dan Investasi), 2(2), 81-97.

Sarwono, J., 2016, "Prosedur-Prosedur Analisis Populer Aplikasi Riset Skripsi dan Tesis dengan Eviews", Gava Media, Yogyakarta.

Sriyana, J, 2014, “Metode Regresi Data Panel”, Ekonisia, Yogyakarta.

Sugiyono, 2014, "Metode Penelitian Kombinasi”, Penerbit Alfabeta, Bandung.

Weston, J.F. dan Copeland, T.E., "Manajemen Keuangan Edisi Kesembilan Jilid 1", Penerbit Binarupa Aksara, Grogol.

Widarjono, A., 2007, "EkonometrikaTeori dan Aplikasi untuk Ekonomi dan Bisnis", Ekonisia, Yogyakarta.

Wild, J. J., Subramanyam, K. R. dan Halsey, R. E., 2005, "Financial Statement Analysis", Salemba Empat, Jakarta.

Winarno, W. W., 2015, “Analisis Ekonometris dan Statistika dengan EViews”, UPP STIM YKPN, Yogyakarta. 